\title{
OPEN
}

Published online: 06 March 2020

\section{Author Correction: A recombinant avian paramyxovirus serotype 3 expressing the hemagglutinin protein protects chickens against H5N1 highly pathogenic avian influenza virus challenge}

Edris Shirvani, Berin P. Varghese, Anandan Paldurai \& Siba K. Samal

Correction to: Scientific Reports https://doi.org/10.1038/s41598-020-59124-x, published online 10 February 2020 In this Article, Figure 6 is a duplication of Figure 8. The correct Figure 6 appears below as Figure 1.

A)

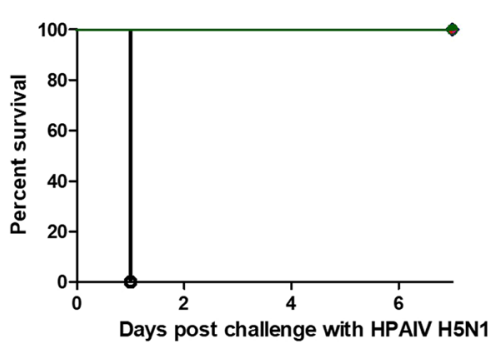

B)

Groups

$\rightarrow A$

$\diamond B$

$\diamond C$

$\rightarrow D$

$\rightarrow E$

$\rightarrow F$
$\mathrm{HI}$ antibody titers against LPAIV H5N2

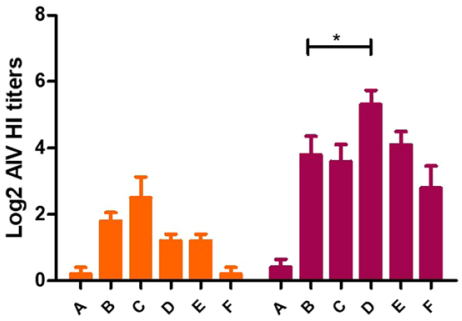

Figure 1.

3 weeks post-prime 2-weeks post-boost

(c) (i) Open Access This article is licensed under a Creative Commons Attribution 4.0 International By License, which permits use, sharing, adaptation, distribution and reproduction in any medium or format, as long as you give appropriate credit to the original author(s) and the source, provide a link to the Creative Commons license, and indicate if changes were made. The images or other third party material in this article are included in the article's Creative Commons license, unless indicated otherwise in a credit line to the material. If material is not included in the article's Creative Commons license and your intended use is not permitted by statutory regulation or exceeds the permitted use, you will need to obtain permission directly from the copyright holder. To view a copy of this license, visit http://creativecommons.org/licenses/by/4.0/.

(c) The Author(s) 2020 